\title{
A RENEWABLE CATALYST FOR A RENEWABLE CHEMICAL: GRAM-SCALE CONVERSION OF FURFURAL TO FURFURYL ALCOHOL BY THE CARROT (Daucus carota)
}

\author{
Alvaro T. Omori*a, ${ }^{\text {, }}$, Marina G. Capeletto ${ }^{a}$, Daniela Y. Yamamoto ${ }^{a}$ and Ronaldo E. de Oliveira Filho ${ }^{a}$ \\ ${ }^{a}$ Centro de Ciências Naturais e Humanas, Universidade Federal do ABC, 09210-580 Santo Andre - SP, Brasil
}

Recebido em 14/06/2019; aceito em 27/08/2019; publicado na web em 03/12/2019

\begin{abstract}
The bioconversion of furfural to furfuryl alcohol using only carrot bits in water at room temperature and ambient pressure is presented. This reaction led to the bioreduction of furfural with $99 \%$ conversion and $99 \%$ selectivity to an alcohol. This simple and "fully" green process may represent an alternative to classic hydrogenation processes. Also, without work-up procedure, we demonstrate the aqueous solution can be submitted to microwave irradiation to obtain 4-hydroxy-2-cyclopentenone.
\end{abstract}

Keywords: furans; biomass; biocatalysis and sustainable process.

\section{INTRODUCTION}

Currently, chemicals derived from biomass are of great interest in academia. ${ }^{1}$ Considering the environmental issues caused by the over-consumption of fossil fuels, the development of new processes to produce high value-added chemicals in biorefineries is of great value. ${ }^{2}$ Furans derived from dehydration of $\mathrm{C} 5$ and $\mathrm{C} 6$ carbohydrates, for example, have been considered the "new" top biobased products from biorefinery carbohydrates by the US Department of Energy. ${ }^{3}$ According to the authors, catalytic systems for reactions in aqueous solution are needed for this type of platform (furans). Therefore, furfural (1) is being considered one of the most promising renewable chemicals derived from lignocellulosic biomass. The number of publications related to the synthesis and use of furfural is increasing exponentially. ${ }^{4}$ In addition, the corresponding furfuryl alcohol (2) is considered to be the most important chemical derived from $\mathbf{1}$ and has a broad spectrum of applications in the chemical industry. The industrial processes used to convert $\mathbf{1}$ to $\mathbf{2}$ are already established but still depend on $\mathrm{Cu}$ catalysts, which require high temperatures and the use of hazardous and explosive hydrogen. On the other hand, biocatalytic reduction of furfural remains incipient; consequently, scalability of biocatalytic reduction is a difficult task to overcome. Except for the fermentative formation of furfuryl alcohol in a high concentration of furfural ( $\left.35 \mathrm{~g} \mathrm{~L}^{-1}\right)$ using Saccharomyces cerevisiae $354,{ }^{5}$ biotransformation of $\mathbf{1}$ using whole-cell systems has a limited scope. The use of aseptic conditions in addition to the acquisition of specific strains and the time and growth media utilized in the growing step make the process unfeasible for the reduction of a large-scale commodity chemical. For example, the recent one-pot chemoenzymatic synthesis of furfuryl alcohol from xylose involves whole-cell bioreduction of furfural ${ }^{6}$ Although the reduction occurs at a high concentration $\left(200 \mathrm{mmol} \mathrm{L}^{-1}\right)$, it requires temperature control, a specific $\mathrm{pH}$ buffer, glucose as an additive and the prior growth of a specific strain of Escherichia coli. Additionally, the reaction volume tested was only $10 \mathrm{~mL}$.

To circumvent the microbiological issues but still use enzymes as natural catalysts, we present a very simple and environmentally friendly alternative to obtain furfuryl alcohol by bioreduction mediated by carrots.

\section{EXPERIMENTAL}

\section{Materials}

Furfural was kindly provided by Professor Mirela Sairre (UFABC/ Brazil) and was distilled prior to use. Other chemical reagents were of analytical grade (ethanol, glucose and ethyl acetate from Synth ${ }^{\circledR}$, Diadema, Brazil; furfuryl alcohol from Sigma Aldrich, USA). Carrots (Daucus carota ssp sativus var. sativus) were purchased at a local market (Carrefour, Brazil).

\section{Bioreduction reaction}

All experiments were conducted on an orbital shaker (IKA® KS 130 Control) at room temperature.

The general procedure was as follows: distilled water, $5 \mathrm{~mm}$ carrot slices and furfural were added to an Erlenmeyer flask $(125 \mathrm{~mL}$ to $1 \mathrm{~L}$ capacity) and were stirred at $180 \mathrm{rpm}$ for two or three days. Aliquots $(1 \mathrm{~mL})$ were collected into a $1.5 \mathrm{~mL}$ tube every 24 hours and were submitted for gas chromatography (GC) analysis. For smallscale reactions, the experiments were usually conducted with $5 \mathrm{~g}$ of carrot, $50 \mathrm{~mL}$ of distilled water and $100 \mu \mathrm{L}$ of furfural in a $125 \mathrm{~mL}$ Erlenmeyer flask. For the gram-scale reactions, we used $120 \mathrm{~g}$ of carrot, $200 \mathrm{~mL}$ of water and $1 \mathrm{~g}$ of furfural in a $1 \mathrm{~L}$ Erlenmeyer flask.

\section{GC analyses}

Each aliquot was extracted with $0.5 \mathrm{~mL}$ of ethyl acetate, and the organic phase was submitted to GC-FID analysis. All chromatograms were recorded on a 450-GC (Bruker) with a Chirasil-Dex CB- $\beta$ cyclodextrin $25 \mathrm{~m} \times 0.25 \mathrm{~mm}$ column using $\mathrm{H}_{2}$ as the carrier gas. The chromatographic conditions were as follows: injector temperature: $250{ }^{\circ} \mathrm{C}$; front inlet pressure: $68.9 \mathrm{kPa}$; detector temperature: $270{ }^{\circ} \mathrm{C}$; and split ratio: 1:20. The oven temperature program included an initial temperature of $60{ }^{\circ} \mathrm{C}$ for 2 minutes, temperature rate of $10{ }^{\circ} \mathrm{C} / \mathrm{min}$ and final temperature of $175^{\circ} \mathrm{C}$. Commercial samples of furfural and furfuryl alcohol were also analyzed.

The retention time for furfural (1) was $5.00 \mathrm{~min}$.

The retention time for furfuryl alcohol (2) was $7.27 \mathrm{~min}$. 


\section{Extraction and product analysis}

After completion of the bioreduction reaction, the suspension was filtered and the carrot root was washed two times with ethyl acetate. The filtrates were then extracted three times with ethyl acetate in a separatory funnel. The organic phases were combined, dried with $\mathrm{Na}_{2} \mathrm{SO}_{4}$, filtered and evaporated under reduced pressure. The final product was analyzed directly by ${ }^{1} \mathrm{H}$ and ${ }^{13} \mathrm{C}$ NMR without further purification.

The isolated yield was calculated as follows:

Furfuryl alcohol yield $(\%)=($ mols of $2 /$ mols of $\mathbf{1}) \times 100$

\section{NMR analysis}

${ }^{1} \mathrm{H}$ NMR and ${ }^{13} \mathrm{C}$ NMR were performed on a Varian NMR $(500 \mathrm{MHz})$ from Federal University of $\mathrm{ABC}$ and were reported in parts per million (ppm) on the $\delta$ scale relative to tetramethylsilane (TMS) as an internal standard.

The NMR data are in agreement with literature. ${ }^{7}$ Furfuryl alcohol (2): ${ }^{1} \mathrm{H} \mathrm{NMR}\left(500 \mathrm{MHz}, \mathrm{CDCl}_{3}\right) \delta 2.69(\mathrm{~s}, 1 \mathrm{H}, \mathrm{OH} l), 4.56(\mathrm{~s}, 2 \mathrm{H}$, $\left.\mathrm{CH}_{2} 2\right), 6.27$ (dd, $\left.J=3.3,0.8 \mathrm{~Hz}, 1 \mathrm{H}, \mathrm{CH} 4\right), 6.33(\mathrm{dd}, J=3.3,1.9 \mathrm{~Hz}$, $1 \mathrm{H}, \mathrm{CH} 5), 7.39$ (dd, $J=1.9,0.8 \mathrm{~Hz}, 1 \mathrm{H}, \mathrm{CH} 6) .{ }^{13} \mathrm{C} \mathrm{NMR}(125 \mathrm{MHz}$, $\mathrm{CDCl}_{3}$ ) $\delta 57.2(\mathbf{C} 2), 107.7(\mathbf{C} 4), 110.4(\mathbf{C} 5), 142.5$ (C6), $145.0(\mathbf{C} 3)$

\section{Piancatelli rearrangement}

After completion of a small-scale bioreduction of $\mathbf{1}$ monitored TLC or GC, $6 \mathrm{~mL}$ aliquot was transferred to a $15 \mathrm{~mL}$ ACE pressure tube. The reaction mixture was irradiated with microwave at $250 \mathrm{~W}$ for $20 \mathrm{~min}$ (limit temperature $140{ }^{\circ} \mathrm{C}$ ). After completion the mixture was transferred to a $50 \mathrm{~mL}$ falcon tube, and freeze-dried, yielding $106 \mathrm{mg}$ (72\% isolated yield) of $\mathbf{3}$ as a yellow oil.

The NMR data are in agreement with literature. ${ }^{8}$ 4-hydroxy-2cyclopentenone 3: ${ }^{1} \mathrm{H} \mathrm{NMR}\left(500 \mathrm{MHz}, \mathrm{CDCl}_{3}\right) \delta 2.28\left(\mathrm{dd}, 1 \mathrm{H}, \mathrm{CH}_{2}\right)$, 2.62 (s, $1 \mathrm{H}, \mathrm{OH}), 2.78$ (dd, 1H, $\left.\mathrm{CH}_{2}\right), 5.05(\mathrm{~m}, 1 \mathrm{H}, \mathrm{CH}-\mathrm{COH}), 6.22$ $(\mathrm{dd}, 1 \mathrm{H}, \mathrm{C}=\mathrm{CH}), 7.57(\mathrm{dd}, 1 \mathrm{H}, \mathrm{C}=\mathrm{CH}), 7.39(\mathrm{dd}, J=1.9,0.8 \mathrm{~Hz}$, $1 \mathrm{H}, \mathrm{CH}) .{ }^{13} \mathrm{C}$ NMR $\left(125 \mathrm{MHz}, \mathrm{CDCl}_{3}\right) \delta 44.25$ (C5), 70.38 (C4), 135.11 (C2), 163.29 (C3), 206.72 (C1).

\section{RESULTS AND DISCUSSION}

\section{Optimization for the bioreduction of 1 to 2}

Several parameters were investigated to optimize the reaction conditions. The reagent/catalyst/solvent ratio, carrot source, influence of the functional carbonyl group (aldehyde vs. ketone) and other factors were investigated (Figure 1).<smiles>O=Cc1ccco1</smiles>
furfural, 1

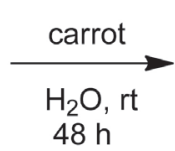<smiles>OCc1ccco1</smiles>

furfuryl alcohol, 2
Figure 1. Scheme of the bioreduction of furfural by carrots

\section{Reagent / catalyst / solvent ratio}

Based on the method to reduce aryl ketones, ${ }^{9}$ the initial attempts were performed in Erlenmeyer flasks under orbital stirring. The carrot was cut into slices (approximately $0.5 \mathrm{~cm}$ each). To avoid any further interference, only one carrot was cut and distributed in all reactions \#1 to \#14 (Table 1). The influence of the substrate amount was investigated in reactions \#1 to \#4, while the influence of the amount of the catalyst was investigated in reactions \#5 to \#8, and the influence of the of the solvent volume was investigated in reactions \#9 and \#10. For the last four reactions (\#11 to \#14), different additives (isopropanol, glucose, sucrose and tryptone) were introduced to evaluate their possible influence on the reaction performance. The results are summarized in Table 1.

The results shown in Table 1 indicate that the conversion was high after 48 hours of reaction. Except for reactions \#3 and \#4, the conversions were low, probably because of the high concentration of the substrate $\left(>96 \mathrm{mmol} \mathrm{L}^{-1}\right)$.

We also observed that all of the reactions in this study showed a high selectivity to furfuryl alcohol (99\% selectivity by GC). In contrast to other chemocatalytic methods, ${ }^{10}$ overreduction of the furan ring did not occur in our reactions. No byproducts were detected when furfural was reacted with carrots in water.

In the case of reactions \#1 to \#4, we observed that the carrot tolerated furfural concentrations of up to $24 \mathrm{mmol} \mathrm{L}^{-1}$ only if the

Table 1. Effects of the furfural concentration, carrot concentration and additive on furfural reduction mediated by carrot bits

\begin{tabular}{|c|c|c|c|c|c|c|c|c|}
\hline \multirow{2}{*}{ Reaction } & \multirow{2}{*}{$\begin{array}{c}\text { Furfural } \\
\left(\mathrm{mmol} \mathrm{L}^{-1}\right)\end{array}$} & \multirow{2}{*}{ Carrot $(\mathrm{g})$} & \multirow{2}{*}{$\mathrm{H}_{2} \mathrm{O}(\mathrm{mL})$} & \multirow{2}{*}{$\begin{array}{l}\text { Carrot conc. } \\
\qquad(\mathrm{g} / \mathrm{L})\end{array}$} & \multicolumn{3}{|c|}{ Conversion* $(\%)$} & \multirow{2}{*}{ Additive } \\
\hline & & & & & $24 \mathrm{~h}$ & $48 \mathrm{~h}$ & $72 \mathrm{~h}$ & \\
\hline$\# 1$ & 24 & 10 & 50 & 200 & 61 & 99 & 99 & \\
\hline$\# 2$ & 6 & 10 & 50 & 200 & 99 & 99 & 99 & \\
\hline$\# 3$ & 96 & 10 & 50 & 200 & 8 & 15 & 16 & \\
\hline$\# 4$ & 193 & 10 & 50 & 200 & 2 & 2.1 & 2.2 & \\
\hline \#5 & 24 & 5 & 50 & 100 & 37 & 99 & 99 & \\
\hline \#6 & 24 & 20 & 50 & 400 & 99 & 99 & 99 & \\
\hline$\# 7$ & 24 & 2.5 & 50 & 50 & 17 & 61 & 99 & \\
\hline \#8 & 24 & 40 & 50 & 800 & 99 & 99 & 95 & \\
\hline \#9 & 12 & 10 & 100 & 100 & 86 & 95 & 99 & \\
\hline$\# 10$ & 6 & 10 & 200 & 50 & 73 & 99 & 99 & \\
\hline \#11 & 24 & 10 & 50 & 200 & 71 & 99 & 99 & isopropanol \\
\hline \#12 & 24 & 10 & 50 & 200 & 67 & 99 & 99 & glucose \\
\hline \#13 & 24 & 10 & 50 & 200 & 64 & 99 & 99 & sucrose \\
\hline$\# 14$ & 24 & 10 & 50 & 200 & 71 & 99 & 99 & Triptone \\
\hline
\end{tabular}

*Determined by gas chromatography (GC). The selectivity for all reactions was $99 \%$. 
biocatalyst concentration was fixed at $200 \mathrm{~g} \mathrm{~L}^{-1}$. When the amount of carrot was varied (reactions \#5 to \#8), we observed that the reaction was completed in less than $24 \mathrm{~h}$ with a catalyst concentration greater than $400 \mathrm{~g} \mathrm{~L}^{-1}$. In the case of reaction \#8, we observed an oxidation of the alcohol after $48 \mathrm{~h}$ of reaction in a lesser extent. This opposite trend can be justified by the high amount of the catalyst.

Since the reaction with $100 \mathrm{~g} \mathrm{~L}^{-1}$ of carrot (reaction \#5) also led to the same conversion after $48 \mathrm{~h}$, we considered the reagent/catalyst/ solvent ratio of $100 \mu \mathrm{L}$ of furfural $/ 5 \mathrm{~g}$ of carrot $/ 50 \mathrm{~mL}$ of $\mathrm{H}_{2} \mathrm{O}$ to be the most promising in this first approach.

Higher amounts of water were also evaluated. In reactions \#9 and $\# 10$, we observed that less concentrated reactions had no influence on the reaction rate because the conversion reached $99 \%$ after $48 \mathrm{~h}$ of reaction.

The possible influence of additives was also investigated. The addition of isopropanol and glucose could help cofactor $\left(\mathrm{NAD}^{+} / \mathrm{NADH}\right)$ recycling during the reaction. However, the reaction proceeded in the same manner as that with only water, carrot and substrate. Analogously, sucrose and tryptone did not affect the reaction. Thus, to minimize costs, further experiments were performed without additives.

For further experiments, we fixed the reaction time to $48 \mathrm{~h}$. Reactions lasting more than 3 days showed little degradation of the catalyst, and extraction of the corresponding alcohol was observed to be more difficult.

The results obtained thus far suggest a detailed study with simultaneous variation of the concentrations of the substrate and catalyst. Table 2 below shows the conversion values when the substrate and carrot concentrations were varied.

Based on the conversion values after $48 \mathrm{~h}$, the results presented in Table 2 suggest that the optimum concentration of furfural for reduction was between 33 and $45 \mathrm{mmol} \mathrm{L}^{-1}$ (reactions \#15 and \#16). Higher concentrations ( $60 \mathrm{mmol} \mathrm{L}^{-1}$ or more) of furfural led to low conversion, even after $48 \mathrm{~h}$ of reaction. The carrot concentration, on the other hand, did not vary sufficiently in regard to its influence on the reaction. We believe that the concentration of carrots (up to $167 \mathrm{~g} \mathrm{~L}^{-1}$ ) investigated in this part weakly affected the conversion to the desired alcohol. Therefore, we investigated the effect of higher concentrations of carrot by performing higher scale reactions as described below.

\section{Gram-scale reaction}

Next, two reactions were conducted using high quantities of furfural (400 $\mathrm{mg}$ and $800 \mathrm{mg}$ ) and the optimized conditions obtained from small-scale reactions $(100 \mu \mathrm{L}$ of furfural $/ 5 \mathrm{~g}$ of carrot $/ 50 \mathrm{~mL}$ of $\mathrm{H}_{2} \mathrm{O}$ ) (Table 3). In these reactions, the conversion values reached $99 \%$ after $48 \mathrm{~h}$, as expected.

The crude product of both reactions was extracted and analyzed by $\mathrm{NMR}{ }^{1} \mathrm{H}$ and ${ }^{13} \mathrm{C}$ (see the supporting information). Although the crude product indicated the production of furfuryl alcohol at high purity, the isolated yields were low. We believe that the low yields were related to the high solubility of furfuryl alcohol in water. Another reason to the low yield can be attributed to a possible polymerization of the furfuryl alcohol. However, the polymerization is commonly observed in the presence of acid catalysts ${ }^{11}$ or in high temperatures ${ }^{12}$

Therefore, tests to improve the yield were performed. The use of an ultrasonic bath or the addition of a saturated solution of $\mathrm{NaCl}$ in the liquid-liquid extraction, for example, did not lead to an increase of the isolated yield. Instead, we only observed a crucial dependence on the amount of ethyl acetate. Extracting three times with ethyl acetate yielded higher amounts of product than when the reaction was extracted only once.

To validate the dependence of the concentrations of furfural and carrot, one gram of furfural was reacted with the highest amount of carrot that could be added without compromising orbital stirring. Thus, with $41 \mathrm{mmol} \mathrm{L}^{-1}$ furfural and $480 \mathrm{~g} \mathrm{~L}^{-1}$ of carrot, we obtained the corresponding alcohol at a reasonable isolated yield (63\%). This result demonstrates that this reaction can be performed at the gram scale. However, when we used twice the concentration of furfural, the reaction led to only $40 \%$ conversion.

\section{Reproducibility}

Another advantage of this presented methodology is that the carrot is available worldwide. ${ }^{13}$ To demonstrate the reproducibility of our results, we tested the reduction of furfural with four different carrots obtained from four different markets. In addition to the carrot used in the reactions presented in Table 1, we used four different carrots for comparison. Figure 2 below shows the conversion performance for each carrot tested.

Table 2. Simultaneous effect of the furfural concentration and carrot concentration on furfural reduction mediated by carrots

\begin{tabular}{|c|c|c|c|c|c|c|}
\hline \multirow{2}{*}{ Reaction } & \multirow{2}{*}{ Furfural $\left(\mathrm{mmol} \mathrm{L}^{-1}\right)$} & \multirow{2}{*}{ Carrot $(\mathrm{g})$} & \multirow{2}{*}{$\mathrm{H}_{2} \mathrm{O}(\mathrm{mL})$} & \multirow{2}{*}{ Carrot conc. (g/L) } & \multicolumn{2}{|c|}{ Conversion* $(\%)$} \\
\hline & & & & & $24 \mathrm{~h}$ & $48 \mathrm{~h}$ \\
\hline \#15 & 24 & 5 & 50 & 100 & 75 & 99 \\
\hline$\# 16$ & 33 & 5 & 45 & 111 & 34 & 99 \\
\hline$\# 17$ & 45 & 5 & 40 & 125 & 21 & 42 \\
\hline$\# 18$ & 60 & 5 & 35 & 143 & 14 & 20 \\
\hline$\# 19$ & 80 & 5 & 30 & 167 & 12 & 16 \\
\hline
\end{tabular}

*Determined by gas chromatography (GC). The selectivity for all reactions was $99 \%$.

Table 3. Bioreduction of $\mathbf{1}$ using carrots at a higher scale

\begin{tabular}{|c|c|c|c|c|c|c|c|}
\hline \multirow{2}{*}{ Reaction } & \multirow{2}{*}{$1 \mathrm{mg}\left(\mathrm{mmol} \mathrm{L}^{-1}\right)$} & \multirow{2}{*}{ Carrot (g) } & \multirow{2}{*}{$\mathrm{H}_{2} \mathrm{O}(\mathrm{mL})$} & \multirow{2}{*}{$\begin{array}{l}\text { Carrot conc. } \\
\qquad(\mathrm{g} / \mathrm{L})\end{array}$} & \multicolumn{2}{|c|}{ Conversion* $(\%)$} & \multirow{2}{*}{$\begin{array}{c}\text { Isolated } \\
\text { yield }(\%)\end{array}$} \\
\hline & & & & & $24 \mathrm{~h}$ & $48 \mathrm{~h}$ & \\
\hline$\# 20$ & $400(21)$ & 20 & 200 & 100 & 62 & 99 & $37 \%$ \\
\hline$\# 21$ & $800(21)$ & 40 & 400 & 100 & 50 & 99 & $44 \%$ \\
\hline \#22 & $1000(41)$ & 120 & 250 & 480 & 73 & 99 & $63 \%$ \\
\hline \#23 & $1600(83)$ & 80 & 200 & 400 & 14 & 40 & n.d. \\
\hline
\end{tabular}

* Determined by GC. The selectivity for all reactions was $99 \%$. 


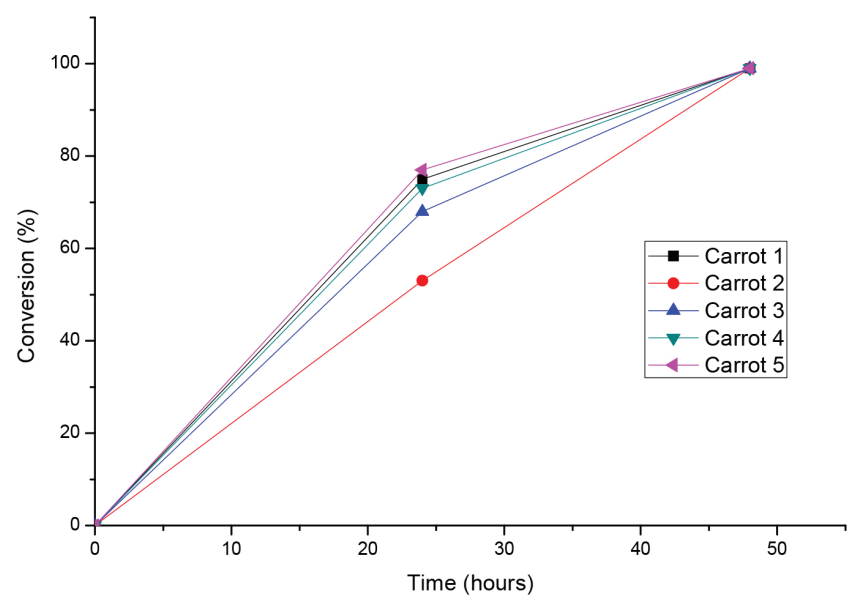

Figure 2. Conversion performance for each carrot tested. Experimental conditions: $100 \mathrm{mg}$ of $1,5 \mathrm{~g}$ of carrot, $50 \mathrm{~mL}$ of $\mathrm{H}_{2} \mathrm{O}$. Conversion determined by $\mathrm{GC}$

As expected, all of the carrots tested led to furfuryl alcohol, with a high conversion after $48 \mathrm{~h}$ of reaction. There is evidence for endophytic microorganisms being the source of the carrot's activity. ${ }^{14,15}$ However, practically, the plant root is the more likely candidate as the source of activity due to simplicity and not requiring the use of microbiological techniques. Nevertheless, the main limitation is associated with the large biocatalyst/substrate ratio (B/S). Catalytically, it is quite controversial that the reaction has a larger mass of catalyst than substrate. Indeed, even if we consider the high water content of vegetables, the dry weight of the catalyst remains high compared with that of the substrate. However, the catalyst is biodegradable and therefore easily disposable. Thus, we consider this limitation to have a smaller impact on the environment than the use of inorganic catalysts.

\section{Function group effect (ketone/aldehyde)}

The results obtained so far indicate that furfural is more reactive in contact with carrots than other substrates (ketones and aldehydes) already reacted by this protocol. To evaluate this, a carrot was equally distributed in two reactions containing furfural and 2-furyl methyl ketone (1a) (Figure 3).

Figure 3 clearly shows that the reaction with aldehyde $\mathbf{1}$ performs

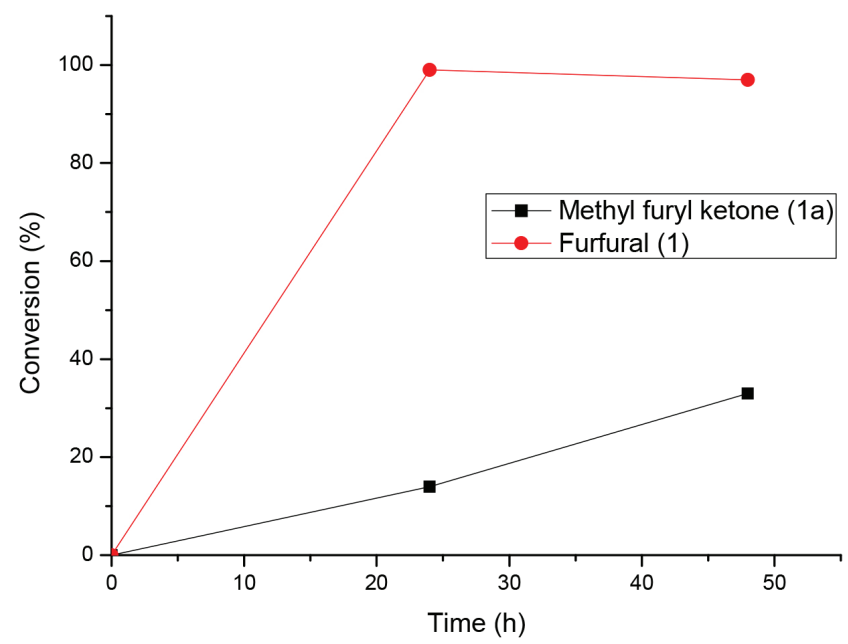

Figure 3. Reactions containing furfural and 2-furyl methyl ketone. Experimental conditions: $21 \mathrm{mmol} \mathrm{L}^{-1}$ of substrate, $5 \mathrm{~g}$ of carrot, $50 \mathrm{~mL}$ of $\mathrm{H}_{2} \mathrm{O}$. Conversion determined by $G C$ better than that with the corresponding ketone 1a. This result can be explained either by the difference in reactivity between aldehydes and ketones, by their solubility difference in water, or by both. In our view, it appears that the solubility of the substrate in water plays a more critical role than the reactivity difference between the functional groups (ketone vs aldehyde). In a previous study, reduction of $\mathrm{N}, \mathrm{N}$-dimethylamino benzaldehyde using carrots was relatively slow, and the data corroborated the low solubility of this compound in water $\left(0.3 \mathrm{~g} \mathrm{~L}^{-1}\right) .{ }^{16}$ However, furfural, another aldehyde, performs better mainly because of its high solubility $\left(>79 \mathrm{~g} \mathrm{~L}^{-1} \text { at } 20^{\circ} \mathrm{C}\right)^{17}$ in water compared with that of the corresponding ketone $\mathbf{1 a}$, which is less soluble $\left(39 \mathrm{~g} \mathrm{~L}^{-1}\right)$. A similar behavior of a higher reactivity of aldehydes than ketones was observed using different plants as biocatalysts. ${ }^{18}$

The solubility issue of the substrate was explored recently. ${ }^{19,20}$ However, furfural is industrially produced at a large scale; thus, we believe it is best to keep the reaction system as simple as possible (water and carrot only).

\section{Piancatelli rearrangement}

One of the several applications of furfuryl alcohol is the conversion to the 4-hydroxy-2-cyclopentenone 3 by Piancatelli rearrangement. ${ }^{21}$ Reiser and coworkers developed a catalyst-free protocol by heating an aqueous solution of furfuryl alcohol (aprox. $0.25 \mathrm{~mol} / \mathrm{L}$ ) at $220^{\circ} \mathrm{C}$ and 15.5 bar under microwave irradiation. ${ }^{22}$ Considering the present sustainable reduction of furfural in water, we investigated if the rearrangement can be conducted directly from the bioreduction reaction.

Initial attempts to achieve such subcritical conditions using commercial furfuryl alcohol in water $\left(0.25 \mathrm{~mol} \mathrm{~L}^{-1}\right)$ failed in our hands. To our surprise, however, we observed the formation of the desired cyclopentenone even at lower temperatures. The results are summarized in Table 4.

Table 4. Application of furfuryl alcohol 2 to obtain 4-hydroxy-2-cyclopentenone $\mathbf{3}$ in water*

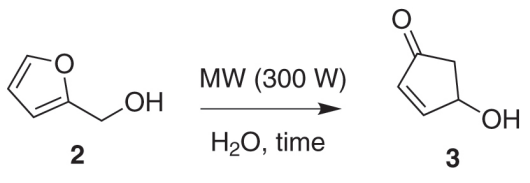

\begin{tabular}{ccc}
\hline $\begin{array}{c}\text { Temperature } \\
\left({ }^{\circ} \mathrm{C}\right)\end{array}$ & $\begin{array}{c}\text { Time of irradiation } \\
\text { (minutes) }\end{array}$ & $\begin{array}{c}\text { Conversion to } \mathbf{3} \\
(\%)^{* *}\end{array}$ \\
\hline 130 & $3 \times 10$ & 78 \\
130 & $5 \times 10$ & 71 \\
140 & $2 \times 20$ & 90 \\
\hline
\end{tabular}

*Reaction conditions: $0.25 \mathrm{~mol} \mathrm{~L}^{-1}$ of $\mathbf{2}, 300 \mathrm{~W}$. **Conversion determined by GC.

Since the concentration of the bioreduction reaction is lower than $0.25 \mathrm{~mol} \mathrm{~L}^{-1}$ of furfural, the Piancatelli rearrangement of furfuryl alcohol could be achieved faster. To validate the feasibility of this hypothesis, in a single run, $250 \mathrm{~mL}$ of aqueous solution of furfural $\left(0.043 \mathrm{~mol} \mathrm{~L}^{-1}\right)$ was reacted with carrot bits. After confirming the formation of $\mathbf{2}$ by GC, a $6 \mathrm{~mL}$ aliquot was transferred to an ACE pressure tube without work-up. After $20 \mathrm{~min}$ of microwave irradiation at $140{ }^{\circ} \mathrm{C}(250 \mathrm{~W})$ we observed $91 \%$ conversion to the desired cyclopentenone 3 . Removal of the $6 \mathrm{~mL}$ of water by lyophilization resulted in $1.08 \mathrm{mmol}$ of $\mathbf{3}$ ( $72 \%$ isolated yield). This result suggests a feasible and safe protocol to obtain 4-hydroxy-2-cyclopentenone in aqueous solution directly from furfural. 


\section{CONCLUSIONS}

We presented a simple method to selectively obtain furfuryl alcohol from furfural after $48 \mathrm{~h}$ by using only water and carrot bits. This reaction is conducted at room temperature without additives or reducing agents and can be set up at the gram scale. The relatively high solubility of furfural in water contributes to the reaction; however, the high solubility of the corresponding alcohol adversely affects the isolated yield. Although the reaction requires very high amounts of carrot, we believe that this barrier does not outweigh the advantages of using this vegetable. The carrot is available worldwide, abundant, cheap, and renewable and has high selectivity. Additionally, after the completion of the reaction, the aqueous solution of the product can be submitted directly to microwave irradiation leading to 4-hydroxy2-cyclopentenone in high conversion.

\section{SUPPLEMENTARY MATERIAL}

NMR ${ }^{1} \mathrm{H}$ and ${ }^{13} \mathrm{C}$ and GC chromatograms for furfuryl alcohol are available from http://quimicanova.sbq.org.br, free of charge.

\section{ACKNOWLEDGMENT}

We express our gratitude to FAPESP (grant ID is 2017/18007-2) for financial support. We also would like to thank Dr. Mirela Ines Sairre for providing furfural.

\section{REFERENCES}

1. Mika, L.T.; Cséfalvay, E.; Németh, A; Chem. Rev. 2018, 118, 505.

2. De Bhowmick, G.; Sarmah, A. K.; Sen, R.; Bioresour. Technol. 2018, 247, 1144.
3. Bozell, J. J.; Petersen, G. R.; Green Chem. 2010, 12, 539.

4. Mariscal, R.; Maireles-Torres, P.; Ojeda, M.; Sádaba, I.; Granados, M. L.; Energy Environ. Sci. 2016, 9, 1144.

5. Diaz de Villegas, M. E.; Villa, P.; Guerra, M.; Rodriguez, E.; Redondo, D.; Martinez, A.; Acta Biotechnol. 1992, 12, 351.

6. He, Y. C.; Jiang, C. X.; Jiang, J. W.; Di, J. H.; Liu, F.; Ding, Y.; Qing, Q.; Ma, C. L.; Bioresour. Technol. 2017, 238, 698.

7. Ambre, R.; Yu, C.; Mane, S. B.; Yao, C.; Hung, C.; Tetrahedron 2011, 67,4680 .

8. Becker, N.; Carreira, E. M.; Org. Lett. 2007, 9, 3857.

9. Comasseto, J. V.; Omori, A. T.; Porto, A. L. M.; Andrade, L. H.; Tetrahedron Lett. 2004, 45, 473.

10. De, S.; Saha, B.; Luque, R.; Bioresour. Technol. 2015, 178, 108.

11. Gandini, A.; Belgacem, M. N.; Prog. Polym. Sci. 1997, 22, 1203.

12. Kong, L.; Guan, H.; Wang, X.; ACS Sustainable Chem. Eng. 2018, 6, 3349.

13. Blanchard, N.; van de Weghe, P.; Org. Biomol. Chem. 2006, 4, 2348.

14. Rodríguez, P.; Barton, M.; Aldabalde, V.; Onetto, S.; Panizza, P.; Menéndez, P.; Gonzalez, D.; Rodríguez, S.; J. Mol. Catal. B: Enzym. 2007, 49, 8

15. Kuila, T.; Bose, S.; Khanra, P.; Mishra, A. K.; Kim, N. H.; Lee, J. H.; Carbon 2012, 50, 914

16. Omori, A. T.; Portas, V. B.; Oliveira, C. S.; Quim. Nova 2012, 35, 435.

17. Stephenson, R. M.; J. Chem. Eng. Data 1993, 38, 630.

18. Suárez-Franco, G.; Hernández-Quiroz, T.; Navarro-Ocaña, A.; OliartRos, R. M.; Valerio-Alfaro, G.; Biotechnol. Bioprocess Eng. 2010, 15, 441.

19. Costa, M. R.; Omori, A. T.; Food Technol Biotechnol. 2017, 55, 231.

20. Xiong, W.; Wang, X.; Kong, L.; Biotechnol Lett. 2015, 37, 1703.

21. Verrier, C.; Moebs-Sanchez, S.; Queneau, Y.; Popowycz, F.; Org. Biomol. Chem. 2018, 16, 676.

22. Ulbrich, K.; Kreitmeier, P.; Reiser, O.; Synlett 2010, 13, 2037. 